\title{
THE ROLE OF SOCIAL NETWORKS IN SUPPORTING COLLABORATIVE E-LEARNING BASED ON CONNECTIVISM THEORY AMONG STUDENTS OF PNU
}

\author{
Dr. Hanan A. ALZAIN \\ ORCID: 0000-0001-6056-237X \\ Faculty of Education, Princess Nourah bint Abdulrahman University \\ Alriyadh, Saudi Arabia
}

Received: 04/06/2018 Accepted: 31/07/2018

\begin{abstract}
The study aimed at identifying the role of social networks (Google and Edmodo) in supporting collaborative elearning based on Connectivism Theory from the perspective of the students of Princess Nourah bint Abdulrahman University (PNU). A questionnaire was designed to identify the most important challenges of collaborative e-learning. Another questionnaire was designed to identify the role of social networks in supporting collaborative e-learning. The quasi-experimental approach was utilized on a sample of (251) students, who utilized social networks in the Educational Technology Course. The results showed that Google and Edmodo have positive impact on supporting collaborative e-learning.
\end{abstract}

Keywords: Social networks, collaborative e-Learning, connectivism theory, e-interaction.

\section{INTRODUCTION}

Educational institutions are no longer the only educational environment for the provision of educational services. Accordingly, educators are keen on exploring the best ways and means to provide an interactive learning environment that attract learners and encourage them to exchange viewpoints and experiences. E-learning is one of the learning techniques that puts learners at the center of learning process. Learners cooperate to obtain and share information and raise ideas to solve problems without commitment to a specific place or time to receive the learning process (Hamdani, 2006). In the mid of 2005, the second generation of e-learning, Computer Supported Collaborative Learning (CSCL) emerged. One of the most prominent reasons for the emergence of this term is the second generation of the Web, which represents a new classification for a number of high speed network-based applications.

CSCL gives learners the opportunity to interact socially and collectively to build a new knowledge structure that enables continuous learning based on the use of technology and modern communication means. Therefore and in the light of information and communication revolution, CSCL should be utilized to prepare an academically qualified and professionally trained teacher. In other words, the development of field training is an important step for improving the process of preparing the student teacher as a whole.

The teacher of Computer, in particular, have to face the rapid and remarkable changes in technological progress and information revolution and the rapid development of devices, programs and communication means. They 
have to encourage their students to be acquainted with innovations in the field of computer and identify and develop their talents in the classroom, school and district levels, motivate them to participate in national and international competitions. Consequently, teachers are required to exert doubled effort and time to acquire newly modern information. Attention should be paid to the preparation of computer student teachers in the light of modern scientific and technological developments, including CSCL.

\section{THEORETICAL FRAMEWORK}

The best type of learning is the one that renders the educational process more interesting and vital; a studentcentered process that places more focus on collaborative projects. Several studies emphasized the significance of the Connectivism Theory in collaborative learning environments through social networks. According to the Connectivism Theory, the base of collaborative e-learning, learning is networks of connections among human (learners, teachers and experts) and non-human (sources of information, books, databases, web, blogs, wiki and chat) nodes. Ideas, emotions, data and new information are also considered nodes, given that connections can take several forms such as interaction between a group of learners, student addition of some comments or student reading of the course content (Siemens, 2005).

Duke et al. (2013) define Connectivism as actionable knowledge, where an understanding of where to find knowledge may be more important than answering how or what that knowledge encompasses. Actually, it is impossible for learners to learn all knowledge, but it can be shared and exchanged with other learners through collaborative e-learning. The most prominent Connectivism Theory-based educational activities, according to Darrow (2009) and Couros (2010), are:

$>$ Constant participation in developing the content of Wiki relating to the course.

$>$ Reading, reviewing and criticizing the basic content through blogs which provide learners with the opportunity to propose their creative ideas that help obtain effective benefit from the educational process.

$>$ Sharing articles through social favorites.

$>$ Preparation of some educational courses that help other learners understand and publishing such courses on the web, Al-Desouky (2015).

Several studies emphasized the significance of the adoption of the Connectivism Theory in the collaborative elearning environment through social networks and its impact on academic achievement and on the development of practical skills as well as the quality of group projects. Among of these studies is Hamada (2014) which concluded that the collaborative e-learning environment based on the Web 2.0 tools tops the traditional eenvironment in developing the skills of managing personal knowledge among students of the Computer course. Anderson and Dron (2011) laid an emphasis on the significance of the Connectivism Theory as a theory of elearning. Both researchers emphasized that education in a collaborative e-learning environment focuses on the formation of networks for information and sources, through which practices, information and activities are shared among the largest number of participants. This is contrary to collaborative e-learning in light of other theories such as the Social Constructive Theory and the Active Learning Theory which focus on learning, interaction and participation through groups.

The Connectivism theory is considered the basis of collaborative e-learning, as Siemens (2005) emphasizes that the Connectivism Theory is an e-learning theory. E-learning is not only the provision of computers and equipment, but also the integration and use of technology to improve the student-centered learning process and 
the learner's positive role in acquiring, analyzing and sharing knowledge. Thus, the teacher must provide students with various educational activities through the utilization of networks.

According to the Connectivism Theory, collaborative e-learning is the outcome of what the teacher introduces through collaborative tools such as social networks, which, in turn, forms a network of varied information that leads to developing learning skills. The Connectivism Theory is a learning theory that demonstrates how communication and information technology created new opportunities for learners to exchange information via social networks; it also focuses on the learning skills necessary for learners to excel and achieve progress in elearning.

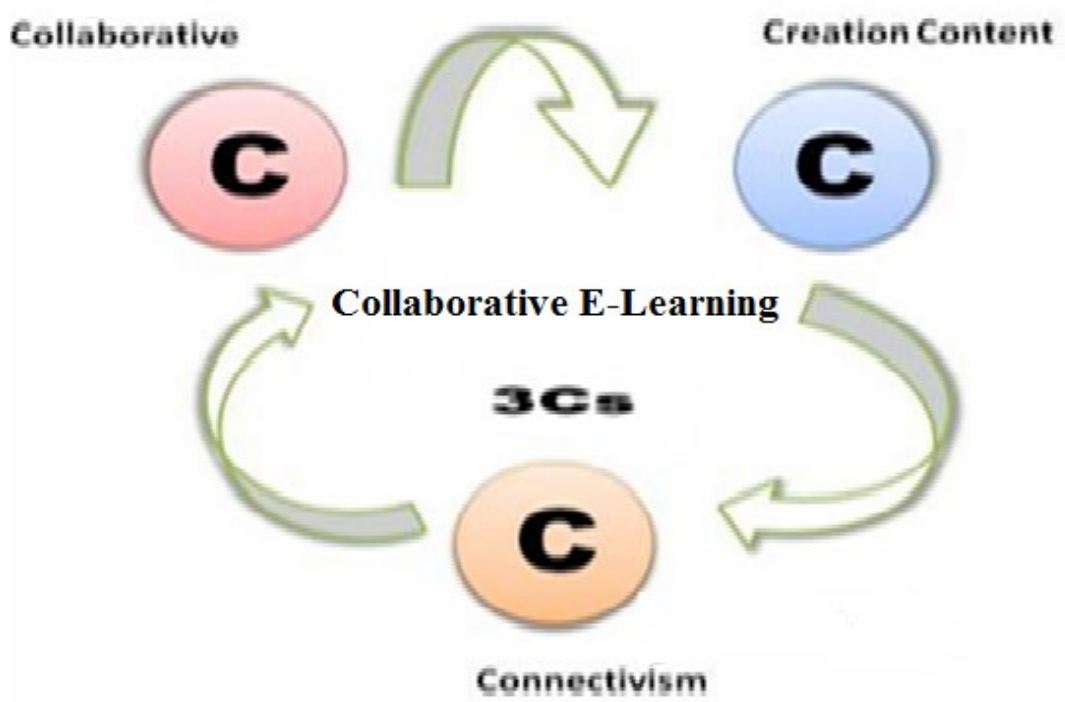

Figure 1. Collaborative E-Learning Process

Collaborative learning is characterized by social and claborative features. Social networks provide students with the opportunity to share, discuss and construct knowledge through interaction, identify relations between concepts, receive feedback and evaluate themselves. According to Venkataraman and Sivakumar (2015), Collaborative E-Learning is one of the best student-centered strategies of e-learning. It depends on social interaction as a basis for knowledge construction and employs online communication technologies to achieve the goals of learning. Consequently, it forms a triangle relationship, i.e. teacher-student-technology relationship, to achieve a fruitful and scalable learning outcomes.

Collaborative e-learning is one of the modern methods designed to improve and motivate the ideas of students working in groups in order to enhance team spirit among students of different abilities, promote knowledge exchange, develop academic achievement, motivate achievement of common tasks, and achieve educational goals. It encourages students to help each other solve any problem they face and share experiences and get feedback from each other (De Hei, 2014). Venkataraman \& Sivakumar (2015) concluded that collaborative elearning contributed to facilitating student's obtaining of feedback and helped students overcome shyness, besides increasing their motivation to share with others to create an effective learning environment. 
Al-Ghool (2012) states that collaborative e-learning passes through inter-related stages, namely preparation, planning, identifying collaborative tasks, transitional stage, implementation, follow-up and support, competition, evaluation and finally self-evaluation stage. As stated by Al-Malah (2013), collaborative e-learning is based on five main principles. First, positive interdependence; achieved when students realize that their success depends on each other and that they have to coordinate their efforts to accomplish their tasks. Second, encouraging direct interaction; i.e. the joint utilization of educational sources and the mutual encouragement and support among students. Third, individual accountability and personal responsibility; it is concerned with providing groups and students with feedback and making sure that each member is responsible for the final

results. Fourth, the skills related to relationships between students and small groups; it focuses on coordination among students to achieve their mutual goals and settle conflicts between them in a positive and constructive manner. Fifth, collective treatment; the group members' discussion of the progress made towards the achievement of their goals and the extent to which their collaborative efforts in the educational process succeeded.

Abdel-Aziz (2010) indicated that collaborative e-learning is a student-centered process that provides learners with significant learning experience through the provision of multiple learning styles, as well as communication skills, critical thinking, division of labor, shared ideas and discussions that take place during the performance of collaborative tasks. It also motivates learners to search for information, explore several new fields and develop learners' skills in the fields of analysis, communication and evaluation.

\section{LITERATURE REVIEW}

According to Rashid et al. (2016), Qing \& Li (2011) and Obaid (2010), social networks allow learners to cooperate together, share and exchange information, identify relations between concepts, receive feedback and evaluate themselves. Khalaf-Allah (2013) indicates that social networks are adequate for applying collaborative e-learning more effectively through supporting collaborative work which involves educational goals while constructing, organizing and publishing content through the collaborative e-learning network.

Social networks are considered a fertile environment for utilizing collaborative e-learning effectively, which is emphasized by Bassiouni (2013) who aimed at identifying the impact of the utilization of the interactive web techniques on designing and producing educational sources and the development of e-participation skills among the students of the Educational Technology Department. The study reached several results, the most of important of which is the significant impact of the interactive web techniques (forum, blog, Facebook) on developing the academic achievement of students and developing e-participation skills due to the provision of tools and potentials that make students interact successfully.

Omar (2013) attempted to provide a proposal for utilizing the tools of social networks, which can be utilized in learning, in the projects of students of the College of Education in Umm Al-Qura University. The model impact was measured in increasing accomplishment motivation and willingness to utilize e-learning among students. The study concluded that there is a positive correlation between the utilization of social networks and the motivation of achievement and the demand for e-learning. In addition, Al-Etibi (2013) came up with the effectiveness of social networks (Twitter) on academic achievement and on the development of collaborative elearning skills. Al-Dariawish (2015) aimed to develop a collaborative training-based system and to measure its effectiveness in developing the skills of using educational drawings among the teachers of deaf students. The study reached the conclusion that there is a significant impact of collaborative training on developing such skills among teachers. 
Ramasubbu (2017) states that Google and Edmodo are among the most popular and open-source social networks as they offer instant messaging, private messages, and different forms of file sharing. Thongmak (2013) further indicates that Edmodo is a free social network that provides teachers and learners with a safe environment for communication, collaboration, sharing of scientific content and digital applications, as well as assignments, grades and discussions. It combines the advantages of Facebook and the Blackboard LMS.

Being a faculty member in PNU, the researcher noticed that students face challenges when it comes to the implementation of collaborative e-learning owing to lack of feedback from teachers, lack of feedback from peers, lack of time to participate, slow internet connectivity, low or no participation of other group members, lack of the clarity required for the assignment or task to be achieved, dependency, domination by one student of the group, non-compliance with the group's objectives, and weak individual follow-up. The present study aimed at identifying the role of social networks in CSEL based on Connectivism Theory among students of PNU.

\section{STATEMENT OF THE PROBLEM}

The problem of the present study can be identified by the limited use of social networks in the educational process in spite of their importance. Due to the difficulties that students face in CSCL, special studies and programs should be developed so that the role of social networks can be activated, and the scientific content can be provided in attractive ways to reach a high level of education. The study attempts to answer the following main question:

What is the role of social networks in supporting collaborative e-learning based on Connectivism Theory among PNU students?

This question gives rise to the following sub-questions:

$>$ What are the collaborative e-learning related challenges faced by PNU students?

$>$ What is the role of social networks in supporting collaborative e-learning from the PNU students' perspective?

$>$ Are there differences in the potentials of collaborative e-learning based on social networks that can be attributed to the used network?

\section{Objectives}

The study attempts to identify the challenges of collaborative e-learning from PNU students' perspectives. It also explores the role of social networks in supporting collaborative e-learning based on Connectivism Theory among PNU students. In addition to identifying the potentials of social networks according to the type of the utilized network. Two social networks adopted and applied with the students of the course of Educational Technology by the teachers of the course, namely Google and Edmodo, which serve as a Learning Management System (LMS) that provides various services through cloud computing.

\section{Significance}

The present study comes as a response to the recent trends in education that call for the necessity of utilizing social networks as an effective educational environment and for developing collaborative e-learning skills. It aims 
at designing a collaborative e-learning environment to support teamwork among students in constructing new knowledge and exchanging viewpoints. Collaborative e-learning tools are utilized in general education, in general, and in higher education, in particular, to achieve constant communication between the teacher and the student.

\section{Limitations}

The study was limited to:

Temporal limitations: the second semester of the academic year 2016-2017.

Spatial limitations: PNU, Saudi Arabia

Human limitations: female students of PNU who are studying Education Technology course.

Objective limitations: social networks (Google) and (Edmodo).

\section{METHODOLOGY AND PROCEDURES}

Method: The descriptive analytical approach utilized in presenting and analyzing the role of social networks in collaborative e-learning.

Population: (434) female students of PNU who study the course of Educational Technology for the Academic Year 2016-1017.

Sampling: the sample consisted of (251) students of PNU, who utilized social networks in the course of Educational Technology. Table (1) shows the distribution of the sample respondents, according to the study variables.

Table. 1 Distribution of the sample based on the study variables

\begin{tabular}{lllll}
\hline \multirow{2}{*}{ Department } & \multicolumn{2}{l}{ The role of social networks } & \multicolumn{2}{l}{ Challenges } \\
& No. & $\%$ & No. & $\%$ \\
\hline Special Education & 170 & 86.3 & 156 & 78.0 \\
Computer & 15 & 7.6 & 24 & 12.0 \\
KG & 12 & 6.1 & 20 & 10.0 \\
Total & 197 & 100.0 & 200 & 100.0 \\
\hline
\end{tabular}

It indicates that response rates of the questionnaire about the role of social networks were $79 \%$ and those of challenges were $80 \%$.

\section{Tools}

To achieve the study objectives, the researcher designed the following tools:

1. A questionnaire was designed to identify the most important challenges of collaborative e-learning from the PNU students' perspective. A list of these challenges developed by reviewing the relevant previous studies to develop the preliminary list of such challenges. The initial form to of the questionnaire submitted to a set of educational specialists and experts to check its validity in terms of items comprehensiveness and appropriateness as well as adding or deleting items. The examiners agreed on the comprehensiveness and appropriateness of the questionnaire to identify the most important challenges of collaborative e-learning from the PNU students' perspective. Necessary modifications were made according to the experts' notes.

2. A questionnaire was designed to identify the role of social networks in supporting collaborative elearning based on the Connectivism Theory from the students' perspective in PNU. The researcher 
developed a list comprising the capabilities of social networks in supporting collaborative e-learning. The tool was developed by deriving the questionnaire paragraphs from previous studies relating to the role of social networks in supporting collaborative learning. The initial form of the questionnaire was submitted to a set of specialists and experts in the educational technology in check to its validity in terms of items comprehensiveness and appropriateness as well as adding or deleting items.

The examiners agreed on the comprehensiveness and appropriateness of the questionnaire to identify the role of social networks in supporting collaborative e-learning based on the Connectivism Theory from the students' perspective in PNU.

\section{Tool Validity}

The validity of the tool was identified using Pearson correlation coefficient between the individual item score and the total score of the questionnaire. Correlation coefficient between the individual item score and the total score of the questionnaire is positive and statistically significant at the level of (0.05), which emphasizes the validity of each item. It also assures the internal correlation among the items of the questionnaire.

\section{Reliability}

To identify the reliability of the questionnaire, alpha Cronbach was adopted and the correlation coefficient was (.883) which is high, given that Abu-Hashem (2004) states that if the correlation coefficient reaches up to $80 \%$, it is considered high.

\section{RESULTS AND DISCUSSIONS}

To answer the first question, what are the challenges facing PNU students in collaborative e-learning, the data collected from the sample by the questionnaire were analyzed. The descriptive statistics utilized and the frequencies, percentages, arithmetic mean and standard deviation were calculated for each item, and then for each axis. Table (2) shows the arithmetic mean of the sample responses.

Table 2. Difficulties of collaborative e-learning via the web from PNU students' perspective

\begin{tabular}{|c|c|c|c|c|c|c|c|c|c|}
\hline No & Items & $\begin{array}{l}\text { Strongly } \\
\text { agree }\end{array}$ & Agree & Neutral & Disagree & $\begin{array}{l}\text { Strongly } \\
\text { disagree }\end{array}$ & mean & $\begin{array}{l}\text { Standard } \\
\text { deviation }\end{array}$ & Order \\
\hline \multirow[t]{2}{*}{1} & Weak cooperation among group & 70 & 78 & 19 & 27 & 4 & \multirow[b]{2}{*}{3.92} & \multirow{2}{*}{1.08} & 30 \\
\hline & students. & 35 & 39 & 9.5 & 13.5 & 2 & & & \\
\hline \multirow[t]{2}{*}{2} & Irresponsibility among some group & 97 & 77 & 9 & 14 & 2 & \multirow{2}{*}{4.27} & \multirow{2}{*}{0.91} & 12 \\
\hline & students & 48.5 & 38.5 & 4.5 & 7 & 1 & & & \\
\hline \multirow[t]{2}{*}{3} & Large number of students in the group & 32 & 48 & 28 & 79 & 12 & \multirow{2}{*}{3.05} & \multirow{2}{*}{1.24} & 40 \\
\hline & & 16 & 24 & 14 & 39.5 & 6 & & & \\
\hline \multirow[t]{2}{*}{4} & Small number of students in the group & 34 & 48 & 27 & 65 & 25 & \multirow{2}{*}{3.01} & \multirow{2}{*}{1.33} & 41 \\
\hline & & 17 & 24 & 13.5 & 32.5 & 12.5 & & & \\
\hline \multirow[t]{2}{*}{5} & Lack of consistency among students in & 83 & 73 & 18 & 22 & 3 & \multirow{2}{*}{4.06} & \multirow{2}{*}{1.04} & 19 \\
\hline & the group & 41.5 & 36.5 & 9 & 11 & 1.5 & & & \\
\hline \multirow[t]{2}{*}{6} & Existence of non-selected students in & 60 & 55 & 14 & 55 & 14 & \multirow{2}{*}{3.46} & \multirow{2}{*}{1.36} & 39 \\
\hline & the group & 30 & 27.5 & 7 & 27.5 & 7 & & & \\
\hline \multirow[t]{2}{*}{7} & Insistence of some students on their & 99 & 73 & 8 & 13 & 5 & \multirow[b]{2}{*}{4.25} & \multirow[b]{2}{*}{0.99} & 13 \\
\hline & $\begin{array}{l}\text { opinion which lead to conflict of } \\
\text { opinions }\end{array}$ & 49.5 & 36.5 & 4 & 6.5 & 2.5 & & & \\
\hline \multirow[t]{2}{*}{8} & Failure of the group if its member are & 101 & 55 & 5 & 30 & 9 & \multirow{2}{*}{4.05} & \multirow{2}{*}{1.24} & 22 \\
\hline & low achievers & 50.5 & 27.5 & 2.5 & 15 & 4.5 & & & \\
\hline \multirow[t]{2}{*}{9} & Dependency of some students in the & 136 & 49 & 5 & 8 & 1 & \multirow{2}{*}{4.56} & \multirow{2}{*}{0.78} & 4 \\
\hline & group on others & 68 & 24.5 & 2.5 & 4 & 0.5 & & & \\
\hline \multirow[t]{2}{*}{10} & Domination of some students over the & 79 & 68 & 17 & 25 & 9 & \multirow{2}{*}{3.92} & \multirow{2}{*}{1.18} & 31 \\
\hline & work & 39.5 & 34 & 8.5 & 12.5 & 4.5 & & & \\
\hline 11 & & 89 & 63 & 15 & 26 & 5 & 4.04 & 1.13 & 24 \\
\hline
\end{tabular}




\begin{tabular}{|c|c|c|c|c|c|c|c|c|c|}
\hline & $\begin{array}{l}\text { Underestimating the achievement of } \\
\text { distinguished students because of other } \\
\text { lower achievers }\end{array}$ & 44.5 & 31.5 & 7.5 & 13 & 2.5 & & & \\
\hline \multirow[t]{2}{*}{12} & Dissatisfaction of distinguished & 64 & 62 & 10 & 46 & 18 & \multirow[b]{2}{*}{3.54} & \multirow[b]{2}{*}{1.38} & \multirow[t]{2}{*}{38} \\
\hline & $\begin{array}{l}\text { students as other lower achievers obtain } \\
\text { equal scores }\end{array}$ & 32 & 31 & 5 & 23 & 9 & & & \\
\hline \multirow[t]{2}{*}{13} & Weak usage of communication & 80 & 58 & 12 & 31 & 18 & \multirow[b]{2}{*}{3.76} & \multirow[b]{2}{*}{1.36} & \multirow[t]{2}{*}{36} \\
\hline & $\begin{array}{l}\text { technology among students in } \\
\text { accomplishing the assignments. }\end{array}$ & 40 & 29 & 6 & 15.5 & 9 & & & \\
\hline \multirow[t]{2}{*}{14} & Difficulty of having a suitable time for & 106 & 61 & 7 & 18 & 5 & \multirow[b]{2}{*}{4.24} & \multirow[b]{2}{*}{1.06} & \multirow[t]{2}{*}{1} \\
\hline & $\begin{array}{l}\text { students to meet and discuss the } \\
\text { procedures of work }\end{array}$ & 53 & 30.5 & 3.5 & 9 & 2.5 & & & \\
\hline 15 & $\begin{array}{l}\text { Selecting members of the group by the } \\
\text { teacher not students }\end{array}$ & $\begin{array}{l}79 \\
39.5\end{array}$ & $\begin{array}{l}45 \\
22.5\end{array}$ & $\begin{array}{l}9 \\
4.5\end{array}$ & $\begin{array}{l}46 \\
23\end{array}$ & $\begin{array}{l}20 \\
10\end{array}$ & 3.59 & 1.45 & 37 \\
\hline 16 & $\begin{array}{l}\text { Lack of technical skills of using the web } \\
\text { among students of the group }\end{array}$ & $\begin{array}{l}64 \\
32\end{array}$ & $\begin{array}{l}86 \\
43\end{array}$ & $\begin{array}{l}15 \\
7.5\end{array}$ & $\begin{array}{l}29 \\
14.5\end{array}$ & $\begin{array}{l}5 \\
2.5\end{array}$ & 3.88 & 1.09 & 33 \\
\hline 17 & $\begin{array}{l}\text { Not setting a specific time for } \\
\text { accomplishing the work. }\end{array}$ & $\begin{array}{l}97 \\
48.5\end{array}$ & $\begin{array}{l}50 \\
25\end{array}$ & $\begin{array}{l}10 \\
5\end{array}$ & $\begin{array}{l}28 \\
14\end{array}$ & $\begin{array}{l}15 \\
7.5\end{array}$ & 3.93 & 1.33 & 28 \\
\hline \multirow[t]{2}{*}{18} & $\begin{array}{l}\text { Student unawareness of the group } \\
\text { learning concept for being familiar with }\end{array}$ & 65 & 95 & 12 & 22 & 3 & \multirow[t]{2}{*}{4.00} & \multirow[t]{2}{*}{0.99} & 25 \\
\hline & traditional methods & 32.5 & 47.5 & 6 & 11 & 1.5 & & & \\
\hline \multirow[t]{2}{*}{19} & $\begin{array}{l}\text { Dependency of some students on the } \\
\text { others }\end{array}$ & $\begin{array}{l}131 \\
65.5\end{array}$ & $\begin{array}{l}57 \\
28.5\end{array}$ & $\begin{array}{l}2 \\
1\end{array}$ & $\begin{array}{l}8 \\
4\end{array}$ & $\begin{array}{l}2 \\
1\end{array}$ & 4.54 & 0.79 & 5 \\
\hline & Difficulty of identifying the size and & 87 & 69 & 13 & 27 & 3 & & & 20 \\
\hline 20 & $\begin{array}{l}\text { type of students' assignments by the } \\
\text { teacher }\end{array}$ & 43.5 & 34.5 & 6.5 & 13.5 & 1.5 & 4.06 & 1.09 & \\
\hline 21 & Lack of interaction among students & $\begin{array}{l}99 \\
49.5\end{array}$ & $\begin{array}{l}78 \\
39\end{array}$ & $\begin{array}{l}9 \\
4.5\end{array}$ & $\begin{array}{l}11 \\
5.5\end{array}$ & $\begin{array}{l}3 \\
1.5\end{array}$ & 4.30 & 0.90 & 8 \\
\hline 22 & $\begin{array}{l}\text { Lack of teachers' follow up of the work } \\
\text { progress }\end{array}$ & $\begin{array}{l}81 \\
40.5\end{array}$ & $\begin{array}{l}58 \\
29\end{array}$ & $\begin{array}{l}11 \\
5.5\end{array}$ & $\begin{array}{l}44 \\
22\end{array}$ & $\begin{array}{l}5 \\
2.5\end{array}$ & 3.83 & 1.25 & 35 \\
\hline 23 & $\begin{array}{l}\text { Taking full responsibility by only some } \\
\text { students in the group }\end{array}$ & $\begin{array}{l}134 \\
67\end{array}$ & $\begin{array}{l}45 \\
22.5\end{array}$ & $\begin{array}{l}2 \\
1\end{array}$ & $\begin{array}{l}12 \\
6\end{array}$ & $\begin{array}{l}7 \\
3.5\end{array}$ & 4.44 & 1.03 & 6 \\
\hline 24 & $\begin{array}{l}\text { Student lack of commitment to } \\
\text { deadlines which may adversely affect } \\
\text { the work progress }\end{array}$ & $\begin{array}{l}145 \\
72.5\end{array}$ & $\begin{array}{l}48 \\
24\end{array}$ & $\begin{array}{l}2 \\
1\end{array}$ & $\begin{array}{l}4 \\
2\end{array}$ & $\begin{array}{l}1 \\
0.5\end{array}$ & 4.66 & 0.65 & 2 \\
\hline 25 & Conflicts between students in the group & $\begin{array}{l}102 \\
51\end{array}$ & $\begin{array}{l}73 \\
36.5\end{array}$ & $\begin{array}{l}8 \\
4\end{array}$ & $\begin{array}{l}15 \\
7.5\end{array}$ & $\begin{array}{l}2 \\
1\end{array}$ & 4.29 & 0.93 & 10 \\
\hline 26 & $\begin{array}{l}\text { Unequal distribution of tasks among } \\
\text { students }\end{array}$ & $\begin{array}{l}109 \\
54.5\end{array}$ & $\begin{array}{l}63 \\
31.5\end{array}$ & $\begin{array}{l}6 \\
3\end{array}$ & $\begin{array}{l}19 \\
9.5\end{array}$ & $\begin{array}{l}2 \\
1\end{array}$ & 4.30 & 0.98 & 9 \\
\hline 27 & $\begin{array}{l}\text { Not identifying responsibilities and } \\
\text { tasks of each student before starting } \\
\text { work }\end{array}$ & $\begin{array}{l}118 \\
59\end{array}$ & $\begin{array}{l}55 \\
27.5\end{array}$ & $\begin{array}{l}6 \\
3\end{array}$ & $\begin{array}{l}16 \\
8\end{array}$ & 4 & 4.34 & 1.01 & 7 \\
\hline 28 & $\begin{array}{l}\text { Existence of some undesirable behavior } \\
\text { in the group such as laziness and } \\
\text { tampering }\end{array}$ & $\begin{array}{l}133 \\
66.5\end{array}$ & $\begin{array}{l}56 \\
28\end{array}$ & $\begin{array}{l}6 \\
3\end{array}$ & $\begin{array}{l}4 \\
2\end{array}$ & $\begin{array}{l}1 \\
0.5\end{array}$ & 4.58 & 0.70 & 3 \\
\hline 29 & $\begin{array}{l}\text { Lack of enthusiasm among students in } \\
\text { the group }\end{array}$ & $\begin{array}{l}100 \\
50\end{array}$ & $\begin{array}{l}73 \\
36.5\end{array}$ & $\begin{array}{l}8 \\
4\end{array}$ & $\begin{array}{l}14 \\
7\end{array}$ & $\begin{array}{l}3 \\
1.5\end{array}$ & 4.28 & 0.94 & 11 \\
\hline 30 & Tasks are not clarified by the teacher & 111 & 47 & 14 & 23 & 5 & 4.18 & 1.13 & 17 \\
\hline & & 55.5 & 23.5 & 7 & 11.5 & 2.5 & & & \\
\hline 31 & $\begin{array}{l}\text { Tasks are not discussed by students in } \\
\text { the group }\end{array}$ & $\begin{array}{l}94 \\
47\end{array}$ & $\begin{array}{l}70 \\
35\end{array}$ & $\begin{array}{l}7 \\
3.5\end{array}$ & $\begin{array}{l}23 \\
11.5\end{array}$ & $\begin{array}{l}5 \\
2.5\end{array}$ & 4.13 & 1.09 & 18 \\
\hline 32 & $\begin{array}{l}\text { Lack of clear criteria for designing and } \\
\text { evaluating the project }\end{array}$ & $\begin{array}{l}109 \\
54.5\end{array}$ & $\begin{array}{l}41 \\
20.5\end{array}$ & $\begin{array}{l}9 \\
4.5\end{array}$ & $\begin{array}{l}34 \\
17\end{array}$ & $\begin{array}{l}7 \\
3.5\end{array}$ & 4.06 & 1.26 & 21 \\
\hline 33 & $\begin{array}{l}\text { Tasks are not suitable with the nature } \\
\text { of learning in the group }\end{array}$ & $\begin{array}{l}88 \\
44\end{array}$ & $\begin{array}{l}54 \\
27\end{array}$ & $\begin{array}{l}13 \\
6.5\end{array}$ & $\begin{array}{l}34 \\
17\end{array}$ & $\begin{array}{l}8 \\
4\end{array}$ & 3.91 & 1.25 & 32 \\
\hline 34 & $\begin{array}{l}\text { Lack of using technology in the } \\
\text { required tasks }\end{array}$ & $\begin{array}{l}84 \\
42\end{array}$ & $\begin{array}{l}67 \\
33.5\end{array}$ & $\begin{array}{l}12 \\
6\end{array}$ & $\begin{array}{l}33 \\
16.5\end{array}$ & $\begin{array}{l}3 \\
1.5\end{array}$ & 3.98 & 1.13 & 26 \\
\hline 35 & $\begin{array}{l}\text { Lack of time and students' being busy } \\
\text { with abundant tasks of other courses }\end{array}$ & $\begin{array}{l}158 \\
79\end{array}$ & $\begin{array}{l}31 \\
15.5\end{array}$ & $\begin{array}{l}3 \\
1.5\end{array}$ & $\begin{array}{l}6 \\
3\end{array}$ & $\begin{array}{l}2 \\
1\end{array}$ & 4.69 & 0.74 & 1 \\
\hline 36 & Dependence on a student to bring the & 114 & 49 & 7 & 25 & 4 & & & 15 \\
\hline & $\begin{array}{l}\text { work to the class to be presented in the } \\
\text { set time. }\end{array}$ & 57 & 24.5 & 3.5 & 12.5 & 2 & 4.23 & 1.12 & \\
\hline
\end{tabular}




\begin{tabular}{|c|c|c|c|c|c|c|c|c|c|}
\hline 37 & $\begin{array}{l}\text { Storing work on damageable tools such } \\
\text { as flash, } \mathrm{CD} \text {, etc. }\end{array}$ & $\begin{array}{l}79 \\
39.5\end{array}$ & $\begin{array}{l}64 \\
32\end{array}$ & $\begin{array}{l}15 \\
7.5\end{array}$ & $\begin{array}{l}33 \\
16.5\end{array}$ & $\begin{array}{l}9 \\
4.5\end{array}$ & 3.86 & 1.23 & 34 \\
\hline \multirow[t]{2}{*}{38} & Dissatisfaction of some distinguished & 94 & 51 & 8 & 40 & 7 & \multirow[b]{2}{*}{3.93} & \multirow[b]{2}{*}{1.28} & 29 \\
\hline & $\begin{array}{l}\text { students as other lower achievers obtain } \\
\text { equal scores }\end{array}$ & 47 & 25.5 & 4 & 20 & 3.5 & & & \\
\hline 39 & $\begin{array}{l}\text { Lack of group discussion of tasks and } \\
\text { work progress }\end{array}$ & $\begin{array}{l}95 \\
47.5\end{array}$ & $\begin{array}{l}72 \\
36\end{array}$ & $\begin{array}{l}11 \\
5.5\end{array}$ & $\begin{array}{l}19 \\
9.5\end{array}$ & $\begin{array}{l}3 \\
1.5\end{array}$ & 4.19 & 1.01 & 16 \\
\hline \multirow[t]{2}{*}{40} & Students' lack of knowledge of using & 86 & 73 & 12 & 22 & 7 & \multirow[b]{2}{*}{4.05} & \multirow[b]{2}{*}{1.12} & 23 \\
\hline & $\begin{array}{l}\text { web } 2.0 \text { tools such as social media to } \\
\text { accomplish the group's project. }\end{array}$ & 43 & 36.5 & 6 & 11 & 3.5 & & & \\
\hline \multirow[t]{2}{*}{41} & Lack of students' skills in & 86 & 63 & 16 & 30 & 5 & \multirow[b]{2}{*}{3.98} & \multirow[b]{2}{*}{1.16} & 27 \\
\hline & $\begin{array}{l}\text { communicating via a personal learning } \\
\text { network }\end{array}$ & 43 & 31.5 & 8 & 15 & 2.5 & & & \\
\hline
\end{tabular}

Table (2) shows that the arithmetic means (4.04) of the challenges facing PNU students in collaborative elearning corresponds to "agree", while the arithmetic means of items ranges between (4.69) and (3.01), corresponding to "strongly agree" and "neutral". Key challenges came as follows: "lack of time and students' being busy with abundant tasks of other courses", the arithmetic means of which reached (4.69) corresponding to 'strongly agree', followed by "students' lack of commitment to deadlines which may adversely affect the work progress" with arithmetic means of (4.66) corresponding to 'strongly agree', then "existence of some undesirable behavior in the group such as laziness and tampering" with arithmetic means of (4.58) which corresponds to "strongly agree", followed by "Inaction of some students and their dependence on others" which arithmetic means is (4.56) corresponding to "strongly agree", and finally came "dependency of come students in the group on others" with arithmetic means of (4.54) corresponding to "strongly agree".

In general, the rest of items received high responses (strongly agree and agree) since students of PNU face challenges in collaborative e-learning. This result is consistent with the studies of (Liu et al., 2010), (Murray \& Boyd, 2015) and (Muuro et al., 2014) that laid emphasize on facing challenges in collaborative e-learning practices.

To answer the second question, what is the role of social networks in supporting collaborative e-learning from PNU students' perspective, data collected from participants through the questionnaire were analyzed. The statistical descriptive method was utilized and frequencies, percentages, arithmetic means, and standard deviation calculated for each item then each domain.

Table 3. The role of social networks in supporting collaborative e-learning from the PNU students' perspective

\begin{tabular}{|c|c|c|c|c|c|c|c|c|c|}
\hline S. & Items & $\begin{array}{l}\text { Strongl } \\
\text { y agree }\end{array}$ & Agree & $\begin{array}{l}\text { Neutra } \\
1\end{array}$ & Disagree & $\begin{array}{l}\text { Strongly } \\
\text { disagree }\end{array}$ & mean & $\begin{array}{l}\text { Standard } \\
\text { deviation }\end{array}$ & $\begin{array}{l}\text { Orde } \\
\mathrm{r}\end{array}$ \\
\hline \multicolumn{10}{|c|}{ First: Collaborative e-learning via social networks fulfills the educational and technical needs of students in PNU by: } \\
\hline \multirow[t]{2}{*}{1} & Assignments related to & 100 & 68 & 3 & 21 & 5 & \multirow{2}{*}{4.20} & \multirow{2}{*}{1.069} & \multirow{2}{*}{26} \\
\hline & student specialization. & 50.8 & 34.5 & 1.5 & 10.7 & 2.5 & & & \\
\hline \multirow[t]{2}{*}{2} & Assignments related to & 92 & 79 & 9 & 14 & 3 & \multirow{2}{*}{4.23} & \multirow{2}{*}{.940} & \multirow{2}{*}{25} \\
\hline & student practical life. & 46.7 & 40.1 & 4.6 & 7.1 & 1.5 & & & \\
\hline \multirow[t]{2}{*}{3} & Integration between & 94 & 85 & 6 & 8 & 3 & \multirow[b]{2}{*}{4.32} & \multirow[b]{2}{*}{.844} & \multirow[b]{2}{*}{22} \\
\hline & $\begin{array}{l}\text { cognitive and technical skills } \\
\text { and the required assignments }\end{array}$ & 47.7 & 43.1 & 3 & 4.1 & 1.5 & & & \\
\hline \multirow[t]{2}{*}{4} & Spending less time on & 107 & 63 & 7 & 19 & 1 & \multirow{2}{*}{4.30} & \multirow{2}{*}{.962} & \multirow{2}{*}{23} \\
\hline & completing the work. & 54.3 & 32 & 3.6 & 9.6 & 0.5 & & & \\
\hline \multirow[t]{2}{*}{5} & Required assignments are & 105 & 64 & 9 & 12 & 6 & \multirow{2}{*}{4.28} & \multirow{2}{*}{1.016} & \multirow{2}{*}{24} \\
\hline & suitable for student level. & 53.3 & 32.5 & 4.6 & 6.1 & 3 & & & \\
\hline
\end{tabular}




\begin{tabular}{|c|c|c|c|c|c|c|c|c|c|}
\hline \multirow[t]{2}{*}{6} & Developing student & 125 & 68 & 3 & 1 & 0.0 & \multirow[t]{2}{*}{4.61} & \multirow[t]{2}{*}{.548} & \multirow[t]{2}{*}{7} \\
\hline & technical skills. & 63.5 & 34.5 & 1.5 & 0.5 & 0.0 & & & \\
\hline \multirow[t]{2}{*}{7} & Facilitating ways of searching & 114 & 70 & 7 & 5 & 0.0 & \multirow{2}{*}{4.49} & \multirow{2}{*}{.691} & \multirow{2}{*}{14} \\
\hline & for various sources. & 57.9 & 35.5 & 3.6 & 2.5 & 0.0 & & & \\
\hline \multirow[t]{2}{*}{8} & Easiness of inserting text & 139 & 48 & 4 & 5 & 1 & \multirow{2}{*}{4.62} & \multirow{2}{*}{.701} & \multirow{2}{*}{5} \\
\hline & files. & 70.6 & 24.4 & 2 & 2.5 & 0.5 & & & \\
\hline \multirow[t]{2}{*}{9} & Easiness of inserting audio & 133 & 44 & 5 & 13 & 1 & \multirow{2}{*}{4.51} & \multirow{2}{*}{.874} & \multirow{2}{*}{13} \\
\hline & files. & 67.5 & 22.3 & 2.5 & 6.6 & 0.5 & & & \\
\hline \multirow[t]{2}{*}{10} & Easiness of inserting photos. & 145 & 44 & 3 & 5 & 0.0 & \multirow{2}{*}{4.67} & \multirow{2}{*}{.637} & \multirow{2}{*}{2} \\
\hline & & 73.6 & 22.3 & 1.5 & 2.5 & 0.0 & & & \\
\hline \multirow[t]{2}{*}{11} & Easiness of inserting videos. & 141 & 42 & 2 & 10 & 2 & \multirow{2}{*}{4.57} & \multirow{2}{*}{.834} & 9 \\
\hline & & 71.6 & 21.3 & 1 & 5.1 & 1 & & & , \\
\hline 12 & Discussions and exchange of & 121 & 58 & 5 & 10 & 3 & 4.44 & 888 & 19 \\
\hline & views on the same document & 61.4 & 29.4 & 2.5 & 5.1 & 1.5 & 1.11 & .000 & 18 \\
\hline 13 & Possibility of amending the & 123 & 48 & 12 & 9 & 4 & 4.41 & 943 & 20 \\
\hline & same document & 62.4 & 24.4 & 6.1 & 4.6 & 2 & 4.41 & .943 & 20 \\
\hline 14 & Increasing commitment & 109 & 61 & 11 & 12 & 3 & 4.33 & .943 & 21 \\
\hline & among students. & 55.3 & 31 & 5.6 & 6.1 & 1.5 & 4.53 & .945 & 21 \\
\hline 15 & Reserving the right of each & 144 & 41 & 4 & 7 & 1 & 4.62 & .743 & 6 \\
\hline & student in the group. & 73.1 & 20.8 & 2 & 3.6 & 0.5 & &.$/ 45$ & \\
\hline 16 & Providing educational & 119 & 63 & 7 & 6 & 2 & & & \\
\hline & $\begin{array}{l}\text { support for students by } \\
\text { faculty members. }\end{array}$ & 60.4 & 32 & 3.6 & 3 & 1 & 4.48 & .793 & 16 \\
\hline 17 & Providing technical support & 121 & 64 & 6 & 5 & 1 & & & \\
\hline & $\begin{array}{l}\text { for students by faculty } \\
\text { members. }\end{array}$ & 61.4 & 32.5 & 3 & 2.5 & 0.5 & 4.52 & .726 & 12 \\
\hline 18 & Identifying the objective of & 117 & 68 & 4 & 7 & 1 & 4.49 & 753 & 15 \\
\hline & required assignments. & 59.4 & 34.5 & 2 & 3.6 & 0.5 & 4.49 & .750 & 1) \\
\hline 19 & Easiness of utilizing web 2.0 & 117 & 73 & 4 & 3 & 0.0 & & & \\
\hline & $\begin{array}{l}\text { tools such as social networks } \\
\text { to facilitate the achievement } \\
\text { of required work. }\end{array}$ & 59.4 & 37.1 & 2 & 1.5 & 0.0 & 4.54 & .618 & 11 \\
\hline 20 & Developing creativity at & 119 & 67 & 6 & 3 & 0.0 & 455 & 635 & 10 \\
\hline & work. & 60.4 & 34 & 3 & 1.5 & 0.0 & $4.5)$ & .05 & 10 \\
\hline 21 & Providing sufficient storage & 122 & 57 & 10 & 7 & 1 & & & \\
\hline & $\begin{array}{l}\text { space on Web (Google } \\
\text { Drive). }\end{array}$ & 61.9 & 28.9 & 5.1 & 3.6 & 0.5 & 4.48 & .793 & 17 \\
\hline 22 & Stored files are less likely to & 124 & 49 & 15 & 9 & 0.0 & 4.46 & 824 & 18 \\
\hline & be lost (Google Drive). & 62.9 & 24.9 & 7.6 & 4.6 & 0.0 & 4.40 & .024 & 10 \\
\hline 23 & Recording all modifications & 135 & 53 & 8 & 1 & & 4.63 & .588 & 4 \\
\hline & made to the file. & 68.5 & 26.9 & 4.1 & 0.5 & & 4.03 & .588 & 4 \\
\hline 24 & Easiness of editing files. & 135 & 52 & 4 & 6 & & 4.60 & .682 & 8 \\
\hline & & 68.5 & 26.4 & 2 & 3 & & & & \\
\hline 25 & Easiness of modifying files. & 145 & 43 & 4 & 4 & & 4.68 & .619 & 1 \\
\hline & & 73.6 & 21.8 & 2 & 2 & & 4.08 & .019 & 1 \\
\hline 26 & Easiness of opening a & 142 & 44 & 10 & 1 & & & & \\
\hline & $\begin{array}{l}\text { collaborative document on } \\
\text { web (Google Drive). }\end{array}$ & 72.1 & 22.3 & 5.1 & 0.5 & & 4.66 & .599 & 3 \\
\hline $\begin{array}{l}\text { The } \\
\text { don }\end{array}$ & $\begin{array}{l}\text { arithmetic means of the } \\
\text { ain. }\end{array}$ & 4.48 & & & & & & & \\
\hline
\end{tabular}


Second: Collaborative e-learning via social networks achieves the concept of e-communication through:

\begin{tabular}{|c|c|c|c|c|c|c|c|c|c|}
\hline \multirow[t]{2}{*}{1} & Requirements of the & 121 & 64 & 1 & 9 & 1 & 4.51 & .775 & 10 \\
\hline & assignment are clear. & 61.4 & 32.5 & 0.5 & 4.6 & 0.5 & & & \\
\hline \multirow[t]{2}{*}{2} & Determine a specific time for & 126 & 64 & 3 & 3 & 1 & 4.58 & .655 & 7 \\
\hline & delivering the assignment. & 64 & 32.5 & 1.5 & 1.5 & 0.5 & & & \\
\hline \multirow[t]{2}{*}{3} & Availability of & 144 & 47 & 2 & 2 & 2 & 4.67 & .653 & 2 \\
\hline & $\begin{array}{l}\text { communication between } \\
\text { students and staff members. }\end{array}$ & 73.1 & 23.9 & 1 & 1 & 1 & & & \\
\hline \multirow[t]{2}{*}{4} & Easiness of sharing files & 145 & 49 & 1 & 2 & & 4.71 & .527 & 1 \\
\hline & $\begin{array}{l}\text { between students and staff } \\
\text { members. }\end{array}$ & 73.6 & 24.9 & 0.5 & 1 & & & & \\
\hline \multirow[t]{2}{*}{5} & Providing the opportunities & 136 & 54 & 2 & 5 & & 4.63 & .639 & 4 \\
\hline & $\begin{array}{l}\text { of instant communication } \\
\text { among students. }\end{array}$ & 69 & 27.4 & 1 & 2.5 & & & & \\
\hline \multirow[t]{2}{*}{6} & $\begin{array}{l}\text { Providing opportunities of } \\
\text { instant electronic }\end{array}$ & 140 & 50 & 4 & 3 & & 4.66 & .599 & 3 \\
\hline & $\begin{array}{l}\text { communication between } \\
\text { students and staff members. }\end{array}$ & 71.1 & 25.4 & 2 & 1.5 & & & & \\
\hline \multirow[t]{2}{*}{7} & Developing communication & 131 & 51 & 8 & 4 & & 4.59 & .671 & 6 \\
\hline & methods between students. & 66.5 & 25.9 & 4.1 & 2 & & & & \\
\hline \multirow[t]{2}{*}{8} & $\begin{array}{l}\text { Providing adequate } \\
\text { communication channels }\end{array}$ & 107 & 61 & 17 & 10 & 2 & 4.32 & .907 & 11 \\
\hline & $\begin{array}{l}\text { such as Google+ and } \\
\text { Hangout. }\end{array}$ & 54.3 & 31 & 8.6 & 5.1 & 1 & & & \\
\hline 9 & $\begin{array}{l}\text { Facilitating access to } \\
\text { collaborative files. }\end{array}$ & $\begin{array}{l}121 \\
61.4\end{array}$ & $\begin{array}{l}63 \\
32\end{array}$ & $\begin{array}{l}9 \\
4.6\end{array}$ & $\begin{array}{l}3 \\
1.5\end{array}$ & & 4.54 & .659 & 8 \\
\hline \multirow[t]{2}{*}{10} & Easiness of verbal & 67 & 57 & 52 & 17 & 4 & 3.84 & 1.055 & 13 \\
\hline & $\begin{array}{l}\text { communication via } \\
\text { Hangout. }\end{array}$ & 34 & 28.9 & 26.4 & 8.6 & 2 & & & \\
\hline \multirow[t]{2}{*}{11} & Easiness if written & 86 & 47 & 46 & 11 & 3 & 4.05 & 1.027 & 12 \\
\hline & $\begin{array}{l}\text { communication via } \\
\text { Hangout. }\end{array}$ & 43.7 & 23.9 & 23.4 & 5.6 & 1.5 & & & \\
\hline \multirow[t]{2}{*}{12} & Enhancing the concept of & 120 & 64 & 8 & 3 & & & & \\
\hline & $\begin{array}{l}\text { communication among } \\
\text { students. }\end{array}$ & 60.9 & 32.5 & 4.1 & 1.5 & & 4.54 & .652 & 8 \\
\hline \multirow[t]{2}{*}{13} & $\begin{array}{l}\text { Enhancing the concept of } \\
\text { communication between }\end{array}$ & 131 & 58 & 6 & 2 & & 4.61 & 601 & 5 \\
\hline & students and staff members. & 66.5 & 29.4 & 3 & 1 & & & & \\
\hline \multicolumn{2}{|c|}{$\begin{array}{l}\text { The arithmetic means of the } \\
\text { domain. }\end{array}$} & 4.48 & & & & & & & \\
\hline
\end{tabular}

Third: Collaborative e-learning via social networks achieves the concept of electronic interaction through:

\begin{tabular}{llllllllll}
\hline 1 & Positive interaction among & 2 & 125 & 64 & 5 & 2 & 4.56 & .725 & 6 \\
& students in the group. & 1 & 63.5 & 32.5 & 2.5 & 1 & 4.62 & .616 & 3 \\
\hline
\end{tabular}




\begin{tabular}{|c|c|c|c|c|c|c|c|c|c|}
\hline & $\begin{array}{l}\text { Interaction between students } \\
\text { and staff members. }\end{array}$ & 66.5 & 31 & 1 & 1 & 0.5 & & & \\
\hline \multirow[t]{2}{*}{3} & Instant electronic interaction & 2 & 196 & 130 & 64 & 2 & \multirow{2}{*}{4.64} & \multirow[t]{2}{*}{.541} & \multirow[t]{2}{*}{2} \\
\hline & among students. & 1 & 99.5 & 66 & 32.5 & 1 & & & \\
\hline \multirow[t]{2}{*}{4} & $\begin{array}{l}\text { Instant electronic } \\
\text { communication between }\end{array}$ & 134 & 62 & & & 1 & \multirow{2}{*}{4.66} & \multirow{2}{*}{.534} & \multirow[t]{2}{*}{1} \\
\hline & students and staff members. & 68 & 31.5 & & & 0.5 & & & \\
\hline \multirow[t]{2}{*}{5} & Enhancing the principle of & 3 & 123 & 64 & 4 & 3 & \multirow[t]{2}{*}{4.58} & \multirow[t]{2}{*}{.616} & \multirow[t]{2}{*}{4} \\
\hline & $\begin{array}{l}\text { participation among } \\
\text { students. }\end{array}$ & 1.5 & 62.4 & 32.5 & 2 & 1.5 & & & \\
\hline \multirow[t]{2}{*}{6} & $\begin{array}{l}\text { Providing suitable channels } \\
\text { for discussion and questions }\end{array}$ & 111 & 57 & 22 & 7 & & \multirow[t]{2}{*}{4.38} & \multirow[t]{2}{*}{.822} & \multirow[t]{2}{*}{8} \\
\hline & $\begin{array}{l}\text { such as Google+ and } \\
\text { Hangout. }\end{array}$ & 56.3 & 28.9 & 11.2 & 3.6 & & & & \\
\hline 7 & $\begin{array}{l}\text { Enhancing cooperation } \\
\text { between students. }\end{array}$ & $\begin{array}{l}116 \\
58.9\end{array}$ & $\begin{array}{l}70 \\
35.5\end{array}$ & $\begin{array}{l}5 \\
2.5\end{array}$ & $\begin{array}{l}4 \\
2\end{array}$ & & 4.53 & .652 & 7 \\
\hline \multirow[t]{2}{*}{8} & $\begin{array}{l}\text { Easiness of interaction with } \\
\text { experts on the local, regional }\end{array}$ & 95 & 58 & 26 & 13 & 5 & \multirow[t]{2}{*}{4.14} & \multirow[t]{2}{*}{1.045} & \multirow[t]{2}{*}{9} \\
\hline & and international level. & 48.2 & 29.4 & 13.2 & 6.6 & 2.5 & & & \\
\hline \multirow[t]{2}{*}{9} & Discussions and exchange of & 122 & 64 & 7 & 2 & & \multirow[b]{2}{*}{4.57} & \multirow[b]{2}{*}{.617} & \multirow[b]{2}{*}{5} \\
\hline & $\begin{array}{l}\text { views on the same } \\
\text { document. }\end{array}$ & 61.9 & 32.5 & 3.6 & 1 & & & & \\
\hline \multicolumn{2}{|c|}{$\begin{array}{l}\text { The arithmetic means of the } \\
\text { domain. }\end{array}$} & 4.50 & & & & & & & \\
\hline \multicolumn{10}{|c|}{ Fourth: Collaborative e-learning via social networks achieves the concept of electronic evaluation through: } \\
\hline \multirow[t]{2}{*}{1} & Providing electronic & 126 & 56 & 9 & 4 & 2 & 4.52 & .766 & 3 \\
\hline & feedback for students. & 64 & 28.4 & 4.6 & 2 & 1 & 4) 2$. &.$/ 00$ & \\
\hline 2 & Identifying lazy students in & 128 & 52 & 7 & 7 & 2 & 4.52 & .813 & 3 \\
\hline & the group by the teacher. & 65 & 26.4 & 3.6 & 3.6 & 1 & & & \\
\hline 3 & $\begin{array}{l}\text { Evaluating the work of each } \\
\text { student. }\end{array}$ & $\begin{array}{l}138 \\
70.1\end{array}$ & $\begin{array}{l}53 \\
26.9\end{array}$ & $\begin{array}{l}3 \\
1.5\end{array}$ & $\begin{array}{l}1 \\
0.5\end{array}$ & $\begin{array}{l}2 \\
1\end{array}$ & 4.64 & .643 & 1 \\
\hline 4 & Easiness of designing & 120 & 56 & 15 & 4 & 2 & & & 5 \\
\hline & $\begin{array}{l}\text { achievement files by students } \\
\text { to be available for the } \\
\text { teacher. }\end{array}$ & 60.9 & 28.4 & 7.6 & 2 & 1 & 4.46 & .805 & \\
\hline 5 & Following up on the progress & 139 & 52 & 2 & 2 & 2 & 4.64 & & 1 \\
\hline & made by each student. & 70.6 & 26.4 & 1 & 1 & 1 & & (6) & \\
\hline & $\begin{array}{l}\text { The arithmetic means of the } \\
\text { domain. }\end{array}$ & 4.55 & & & & & & & \\
\hline & $\begin{array}{l}\text { The arithmetic means of the } \\
\text { questionnaire. }\end{array}$ & 4.49 & & & & & & & \\
\hline
\end{tabular}

Table (3) indicates the role of social networks in supporting collaborative e-learning from the perspective of PNU students. Collaborative e-learning via social networks achieves the concept of electronic evaluation at an arithmetic means +of (4.55) which corresponds to "strongly agree". The arithmetic means of items ranged between (4.64) and (4.46) corresponding to "strongly agree", while the standard deviation of items ranged between (.813) and (.643). The arithmetic means of the item "the possibility of evaluating each student" and "following up on the progress of each student by the teacher" is (4.64), which is the highest arithmetic means. "Electronic feedback for each student" and "identifying lazy students in the group by the teacher" at the 
arithmetic means of (4.46). Such results are consistent with the studies of (Kio, 2015), (Al-Shity, 2013) and (Ibrahim, 2014) emphasized that one of the key challenges of the educational process is the difficulty of participation and interaction between students and teachers outside the class. It is also difficult for the teacher to follow up and evaluating the progress made by each student. Such challenges are overcome through social networks (such as Google and Edmodo) that facilitate the collaborative e-learning process for students synchronously. Okumura \& Bronson (2016), Ali (2015), Pop (2013), Holland \& Muilenburg (2011) and AlRahili (2013) concluded that such social networks enable teachers to follow up and evaluate the progress made by students with regard to required assignments. Through such networks, teachers can become familiarized with all modifications made by students and the type of work they achieved, there by identifying active student easily in collaborative learning. These studies further laid an emphasis on the significance of feedback, which is considered one of effective tools in the educational process between students and teachers. Through feedback, students can inquire about anything at any time which increases students' motivation to ask questions. Feedback also helps increase academic achievement, evaluate learners, develop their skills, increase their self-confidence and develop collaborative e-learning and communication skills.

The third domain "collaborative e-learning via social network achieves the concept of electronic interaction" was ranked second in terms of the highest arithmetic means which is (4.50), corresponding to 'strongly agree'. The arithmetic means of items ranged between (4.66) and (4.14), which corresponds to 'strongly agree'. The arithmetic means of the item "providing the opportunities of instant electronic communication between students and staff members" is (4.66) which is the highest arithmetic means corresponding to 'strongly agree'. The value of its standard deviation reached (.534). "The easiness of interaction with experts at the local, regional and international level" obtained an arithmetic means of (4.14) which is the lowest, corresponding to 'agree' with a standard deviation of (1.045). Such results show that students of PNU agree that social networks (Google and Edmodo) have great potentials and strong role in supporting collaborative e-learning and overcoming its challenges. In a nutshell, collaborative learning via such social networks contributed to overcoming the difficulties of collaborative learning faced by students in PNU.

In general, the remaining items received high responses (strongly agree and agree) since students agree that the utilization of social networks (Google and Edmodo) has a significant role and positive impact on supporting collaborative e-learning and overcoming its challenges. This result is consistent with Clark (2013), Hankins (2015), Ibrahim (2015), Zhou et al. (2012) and Hartung and Harvey (2015) and Holland \& Muilenburg (2011), which reached positive results with regard to such social networks' support of interaction synchronously and asynchronously.

To answer the third question, is there a statistically significant difference between Edmodo and Google from the students' perspectives:, the null hypothesis "there is no statistically significant difference between the mean responses of students in Google and Edmodo" is validated by testing two independent samples. Table (4) indicates the arithmetic means, standard deviation and " $T$ " value of students' responses.

Table 4. Arithmetic means, standard deviation and "T" value of students' responses

\begin{tabular}{llllll}
\hline Social network & No. & $\begin{array}{l}\text { Arithmetic } \\
\text { means }\end{array}$ & $\begin{array}{l}\text { Standard } \\
\text { deviation }\end{array}$ & "T" value & $\begin{array}{l}\text { Level of statistical } \\
\text { significance }\end{array}$ \\
\hline Edmodo & 50 & 237.02 & 17.43 & .378 & .706 \\
Google & 146 & 238.35 & 22.54 & & \\
\hline
\end{tabular}


Table (4) shows that the $(\mathrm{T})$ value $=.378$ which is statistically insignificant at the level of $0.05=\alpha$, which means the validity of the null hypothesis "there is no statistical significance between the mean responses of students in the potentials of Edmodo and Google". In other word, both social networks have the same role due to the great similarity between the characteristics of both networks in terms of interaction, communication, electronic evaluation and fulfilling the educational and technical needs of students. This result is consistent with Zhuo \& Domizi (2012) and Omar (2013) which concluded the effectiveness of Edmodo and Google in the educational process.

\section{CONCLUSION}

According to the study results, the biggest challenge facing PNU students is the lack of time and students being busy with abundant tasks of other courses. It is attributed to the students' commitment to the quizzes, activities, and assignments of various courses studied in one semester. Another challenge is students' lack of commitment to assignment and tasks deadlines which may adversely affect the work progress.

Social networks (Edmodo and google) play an effective role in supporting collaborative e-learning from the perspective of PNU students. Results show that through these networks students are able to interact with the teacher off work hours and classroom. They are able to interact with each other and exchange viewpoints, information and discussions, as they often agreed to log on network simultaneously to communicate and interact with each other. Moreover, the course teacher is able to follow up on student progress in collaborative e-learning, the way they think and the level of their absorption and to provide appropriate feedback for each group. These networks have facilitated e-interaction with local and international experts, they support students in their collaborative tasks. Students were able to easily utilize field experience that strengthens their work with the lowest costs and efforts. Therefore, collaborative e-learning through social networks has contributed to overcoming collaborative e-learning challenges among PNU students.

The results concluded also that Edmodo and Google networks are both effective in terms of interaction, communication and electronic evaluation. In other words, they are capable of meeting the educational and technical needs of PNU students. This effectiveness is due to the several reasons. Social networks (Edmodo and Google) facilitate student participation and interaction with the teacher and with each other outside class time. They enable the teacher to follow up on and evaluate each student work and progress, as the teacher can see all the modifications in terms of its number, quality, and the student who done the work and thus the teacher can easily identify the lazy and the interactive students through these networks. Through feedbacks, students can ask the teacher at anytime and anywhere which increases the motivation among students to ask questions. Feedbacks are important for skills development, achievement increase and learning impact continuity. Furthermore, social networks are effective in learner evaluation, abilities improvement, self-confidence increase, e-collaborative work development and communication skills advancement.

\section{Recommendations:}

$>$ Holding training courses for staff members on the utilization of social networks in the educational process improvement, in general, and collaborative e-learning, in particular.

$>$ Developing Computer courses in colleges and schools to employ social networks e-collaborative learning in the educational process.

$>$ Educational programs developers can utilize the foundations and standards proposed in the current study in designing education programs that depend on social networks collaborative e-learning both at the level of public and university education. 
Daising awareness among students about the role of social networks in supporting collaborative elearning and its impact on improving the educational process

Future studies:

> Conducting a similar study to identify the effectiveness of social networks in supporting collaborative e-learning in various educational stages.

$>$ Conducting a study to identify the effectiveness of social networks in increasing students' motivation towards collaborative e-learning.

$>$ Conducting a study the difficulties facing faculty members when using social networks.

$>$ Design learning environments based on electronic interactions using social networks.

$>$ Conducting a study to identify students' tendencies towards the utilization of social networks in the educational process.

\section{BIODATA and CONTACT ADDRESSES of AUTHOR}

Hanan A. ALZAIN gained her Ph.D. in Educational Technology at October, 2007. Her academic interest areas are e-learning, social network, educational Innovations and multimedia, educational Applications, open and distance learning, education futures, Instructional Design, web 3.0 and use of internet in education. She has over than 9 journal articles published in national indexes. She is a Certified Trainer.

Dr. Hanan A. ALZAIN

Princess Nourah bint Abdulrahman University.

Address: Po box 102247, Riyadh, 11675, Saudi Arabia,

Phone: 00966555292922

E-mail: haalzain@pnu.edu.sa

\section{REFERENCES}

Abdel-Aziz, Y. 2010. Collaborative E-Learning. E-Learning Journal. Retrieved on 1/7/2017 from: http://emag.mans.edu.eg/index.php?sessionID=14\&page=news\&task=show\&id=49

Abu-Hashem, E. 2004. Statistical Manual in Data Analysis Using SPSS, $1^{\text {st }}$ Ed. Riyadh, Al - Rashed Library.

Anderson, T. \& Dron, J. 2011. Three Generations of Distance Education Pedagogy. International Review of Research in Open and Distance Learning, 12 (3), 1-51.

Al-Dariawish, A. 2015. Developing a System Based on Collaborative Web Training and Measuring its Effectiveness in Developing Some of the Skills of Using Educational Fees among Teachers of Deaf Students, International Specialized Educational Journal, 4 (9), pp. 1-26.

Al-Desouky, W. 2015. The impact of Collaborative Learning Through the Web Based on the Connectivism Theory on Academic Self-Efficacy and the Motivation to Work among Students in the Special Diploma of Educational Technology. Arab Studies in Education and Psychology, (62), pp. 129-162.

Al-Etibi, N. 2013. The Effectiveness of Twitter (Microblogging) on the Academic Achievement and the Development of Cooperative Learning Skills among Second-Secondary Students in the Computer Course. A paper presented to the Third International Conference on Education and Distance Learning, Riyadh, Saudi Arabia. 
Al-Ghool, R. 2012. The Effectiveness of an E-Learning Program based on Collaborative Learning in Developing the Skills of Using Web 0.2 Services, E-Learning Magazine, 78 (1), 329-287.

Al-Rahili, T. 2013. The Impact of Using Some of Google Educational Applications in Teaching the Course of Educational Technology on the Academic Achievement and Social Intelligence among the Students of Taibah University. (Unpublished PhD thesis), Umm Al-Qura University, Saudi Arabia.

Al-Shity, I. 2013. The Possibility of Using Cloud Computing Technology in E-Learning at Qassim University. A paper presented at the 3rd International Conference on E-Learning and Distance Learning. Saudi Arabia, Riyadh, 4-7 February.

Al-Malah, T. 2013. Collaborative Learning and Collaborative E-Learning, retrieved on 1/7/2017 from:http://kenanaonline.com/users/tamer2011com/topics/118335\#http://kenanaonline.com/users/tamer2011-com/posts/576430

Bassiouni, N. 2013. The impact of Using Interactive Web Technologies on the Design and Production of Learning Resources and the Development of E-Participation Skills among Students of the Department of Educational Technology. (Unpublished MA thesis), Tanta University, Egypt.

Couros, A. 2010. Developing Personal Learning Networks for Open and Social Learning, Emerging Technologies in Distance Education, 109-127.

Clark, C. 2013. I See You: Using the Affordances of Google+ to Increase Social and Teaching Presence in an Online Undergraduate Teacher Education Course. (Unpublished Master dissertation), University of Nevada, Las Vegas.

Darrow, S. 2009. Connectivism Learning Theory: Instructional Tools for College Courses. (Unpublished Master dissertation), Western Connecticut State University, Danbury, CT.

Duke, Betsy, Harper, Ginger \& Johnston, Mark 2013. Connectivism as a Digital Age Learning Theory, Retrieved on13/4/2017 from: http://www.elearnspace.org/Articles/networks.htm

De Hei, M. S. A., Strijbos, J., Sjoer, E. \& Admiraal, W. 2014. Collaborative Learning in Higher Education: Lecturers' Practices and Beliefs, Retrieved on 28/6/2017 from: http://dx.doi.org/10.1080/02671522.2014.908407

Du, H. S. \& Wagner, Ch. 2011. Collaborative Knowledge Management and E-Learning. Knowledge Management \& E-Learning: An International Journal, 3 (2). 116-118.

Hamdani, E. (2006). E-learning benefits and requirements. Education Mission Journal, (13), 47-48. Oman.

Hankins, S. N. 2015. The Effects of Edmodo on Student Achievement in Middle School. (Unpublished doctoral dissertation), St. Thomas University, Miami Gardens, Florida.

Hartung, K. \& Harvey, T. 2015. Social Media as a Professional Support System for Educational Leaders Our Google+ Hangout Journey, Planning for Higher Education Journal, 43(4), 40-47.

Holland, C. \& Muilenburg, L. Y. 2011. Supporting Student Collaboration: Edmodo in the Classroom, Paper presented at the Society for Information Technology \& Teacher Education International Conference, Tennessee, USA.

Hamada, A. 2014. The Impact of Designing a Collaborative E-Learning Environment Based on Web 2.0 Tools According to the Connectivism Theory on the Development of Personal Knowledge Management Skills. Arab Studies in Education and Psychology, (56), pp. 81- 148. 
Ibrahim, K. (2014). The reality of using social networks in the educational process in the universities of Upper Egypt (field study). Educational sciences, 3 (2), pp. 415- 476.

Ibrahim, W. (2015). "Employment of Social Web Networks in Education", Journal of $\epsilon$-Learning, (15), retrieved on 10/4/2017 from:

http://emag.mans.edu.eg/index.php?sessionID=39\&page=news\&task=show\&id = 492

International Monitor. (2015). Edmodo is a new and effective solution in integrated education, Ministry of Higher Education, (52), pp. 10-15.

Johnson, D. W. \& Johnson, R. T. (2002).Learning Together and Alone: An Overview and Meta-analysis, Asia Pacific Journal of Education, 22(1), 95-105.

Khalaf-Allah, M. (2013). The web-based collaborative learning method. Retrieved on 13/4/2017 from: http://kenanaonline.com/users/azhar-gaper/posts/512866

Obaid, E. (2010). The role of social networks in supporting university courses from the perspective of the Faculty of Computer Science students at Imam Muhammad Ibn Saud Islamic University. A paper presented in the Conference of the Arabic Content on the Internet (challenges and ambition), Riyadh, Saudi Arabia.

Omar, A. 2013. A proposal for the Use of Social Networks in Project-Based Learning and its Impact on Increasing the Motivation for Achievement and the Tendency Towards Web-Based Learning. A paper presented to the 3rd International Conference on Education and Distance Learning Saudi Arabia, Riyadh, 4-7 February.

Kio, S. (2015). Feedback theory through the lens of social networking, Issues in Educational Research, 25(2), $135-152$.

Liu, S., Joy, M., \& Griffiths, N. (2010).Students' perceptions of the factors leading to unsuccessful group collaboration. In Advanced Learning Technologies (ICALT), Paper presented at the IEEE 10th International Conference on, Sousse, Tunisia.

Murray, J., Boyd, S. 2015. A Preliminary Evaluation of Using Web PA for Online Peer Assessment of Collaborative Performance by Groups of Online Distance Learners, International Journal of Elearning and Distance Education, 30(2), Retrieved on13/4/2017 from: http://www.ijede.ca/index.php/jde/article/view/920

Muuro, M. Elizaphan, Wagacha, P. Waiganjo, Oboko, R. \& Kihoro, J. 2014. Students' Perceived Challenges in an Online Collaborative Learning Environment: A Case of Higher Learning Institutions in Nairobi, The International Review of research in open and distributed learning, 15 (6), 132-161.

Okumura, S. \& Bronson, M. 2016. The Use of Edmodo to Enhance Second Language Learning among Japanese and American College Students, Retrieved on 13/4/2017 from:

https://www.researchgate.net/publication/308075963_The_Use_of_Edmodo_to_Enhance_Second_Language _Learning_among_Japanese_and_American_College_Students

Pop, A. 2013. Edmodo E-portfolios in EFL - A Case Study, Paper prepared for presentation at the 8th International Conference on Virtual Learning ICVL, Krabi, Thailand.

Qing, F. \& Li, L. 2011. Web-based Collaborative Learning, Procedia Environmental Sciences, 11, 189 - 192. 
Rashid, A., Shukor, N. \& Tasir, Z. 2016. Using computer-based scaffolding to improve students' reasoning skills in collaborative learning, Paper presented at the IEEE 8th International Conference on Engineering Education (ICEED).

Ramasubbu, S. 2017. Social Apps in Education, Retrieved on14/4/2017 from: http://www.huffingtonpost.com/suren-ramasubbu/social-apps-in-education_b_9518486.html

Siemens, G. 2005. Connectivism: A Learning Theory for the Digital Age, Retrieved on 13/4/2017 from: http://www.itdl.org/journal/jan_05/article01.htm

Thongmak, M. 2013. Social Network System in Classroom: Antecedents of Edmodo Adoption, Journal of eLearning and Higher Education, Vol. 2013, 1-15.

Venkataraman, S. \& Sivakumar, S. 2005. Engaging Students in Group Based Learning Through E-Learning Techniques in Higher Education System. International Journal of Emerging Trends in Science and Technology, 2 (1), 1741-1746.

Zhou, W., Simpson, E. \& Domizi, D. Pinette. 2012. Google Docs in an Out-of-Class Collaborative Writing Activity, International Journal of Teaching and Learning in Higher Education, 24 (3), 359-375. 